\title{
PENGEMBANGAN BAHAN AJAR MENULIS PUISI SISWA KELAS VII SMP NEGERI 1 PAGARALAM
}

\section{(Development of Teaching Material in Poetry to the Eighth Grade Students of SMP Negeri 1 Pagaralam)}

\author{
Henny Nopriani \\ STKIP Muhammadiyah Pagaralam \\ Jalan Kombes Haji Umar Kota Pagaralam Sumatera Selatan \\ Pos-el: nopriani_henny@yahoo.com \\ tanggal naskah masuk 27 April 2019 \\ tanggal akhir penyuntingan 16 Juni 2019
}

\begin{abstract}
Abstrak
The research aims to describe the result of needing, development, evaluation of validation, and describes the potential effects of teaching materials of writing poetry of seventh graders of SMP N 1 Pagarlam. The research was developmentt research. Validation conducted of realibility of the materials, presentation, linguistic, and chart using 5. The research subject were seventh graders of expert validation, the teaching materials of writing poetry can be categorized validity for use. The result of writing poetry test of heroism showed increasing from 59.09 to 80.95. and 21 difference while, the result of writing poetry test of friensdship showed increasing from 56.68 to 76.54 and 19.86 difference. This, teaching material of writing poetry the development outcome of researcher can improve student's understanding of writing poetry.
\end{abstract}

Keywords: development, teaching materials, writing poetry

\section{Abstrak}

Penelitian bertujuan untuk mendeskripsikan hasil kebutuhan, pengembangan, evaluasi dari validasi, dan mendeskripsikan efek potensial bahan ajar menulis puisi siswa kelas Vll SMP Negeri 1 Pagaralam. Penelitian menggunakan penelitian pengembangan.Validasi dilakukan terhadap kelayakan materi, penyajian, kebahasaan, dan kegrafikaan menggunakan angket skala 5. Subjek penelitian ini adalah siswa kelas VII SMP Negeri 1 Pagaralam yang berjumlah 22 siswa. Berdasarkan analisis validasi ahli, bahan ajar menulis puisi dapat dikategorikan layak untuk digunakan. Hasil tes menulis puisi kepahlawanan memperlihatkan peningkatan dari 59,09 menjadi 80,95, dan selisih 21. Sementara hasil tes menulis puisi sahabat menunjukkan peningkatan dari 56,68 menjadi 76,54, dan selisih 19,86. Dengan demikian, bahan ajar menulis puisi hasil pengembangan peneliti dapat meningkatkan pemahaman siswa terhadap menulis puisi.

Kata-kata kunci: Pengembangan, bahan ajar, menulis puisi

\section{PENDAHULUAN}

Menulis puisi menduki peranan penting dalam proses belajar dan pembelajaran. Hal ini disebabkan dengan menulis puisi siswa dapat mengukapkan pengalaman baik yang dialami diri sendiri, orang lain yang diungkapkan melalui katakata yang indah dalam bait-bait puisi 
Menurut (Maulana, 2011) dengan menulis puisi siswa bukan hanya menulis pengalaman saja, melainkan membantu siswa mengolah bahasa lebih luas melalui ungkapan-ungkapan yang ditulis dalam bait-bait puisi. Sejalan dengan pendapat tersebut, (Sofyan, Wiryotinoyo, \& Sudaryono, 2011) menyatakan bahwa menulis puisi dipandang semakin penting dalam aktivitas belajar. Hal ini disebabkan, menulis puisi dapat menambahkan keterampilan siswa dalam menggunakan bahasa dan menambahkan nilai positif terhadap karya sastra.

Namun, kenyataannya, kondisi pembelajaran menulis puisi pada siswa SMP Negeri 1 Pagaralam memiliki beberapa Kesulitan. Salah satu faktor yang menjadi penyebab kesulitan dalam menulis puisi yaitu kurangnya ketersediaan bahan ajar yang memuat bagaimana langkahlangkah menulis puisi. Hal ini berpengaruh terhadap proses belajar siswa dalam menulis puisi.

Berdasarkan survei yang dilakukan oleh peneliti, bahan ajar yang digunakan oleh guru SMP Negeri 1 Pagaralam yaitu buku wajib atau pokok dan buku penunjang.

Buku wajib yang digunakan oleh guru dan siswa. Bila ditinjau dari unsurunsur yang perlu dipahami dalam bahan ajar, diketahui hal-hal berikut. Pertama, buku teks tidak menyajikan petunjuk belajar. Kedua, buku teks yang digunakan tidak menyajikan indikator pencapaian hasil belajar siswa. Semestinya di dalam buku teks terdapat indikator. Hal ini sangat penting, karena sebagai spesifikasi kualitas yang harus dikuasai peserta didik setelah mengikuti pembelajaran.

Ketiga, informasi pendukung. Informasi pendukung di dalam buku teks memuat materi, bahasa, dan ilustrasi gambar. Dilihat dari materi, buku teks yang digunakan guru dan siswa kurang lengkap. Hal ini dapat dilihat dari materi yang tidak menyajikan langkah-langkah menulis puisi, contoh puisi yang tidak bervariasi, tema yang akan ditulis menjadi puisi tidak ditentukan.

Keempat, di dalam buku teks tidak terdapat rubrik penilaian pada setiap akhir pembelajaran. Padahal penilaian sangat penting untuk mengukur sejauh mana siswa telah menguasai materi pembelajaran yang disajikan dalam buku tersebut. Kelima, buku teks tidak disajikan evaluasi pada setiap kompetensi dasar.

Selain buku wajib, peneliti juga melakukan survei pada buku penunjang guru yang diterbitkan oleh lembaga swasta. Dilihat dari segi unsur-unsur buku diketahui hal-hal seperti berikut. Pertama, dalam buku teks tidak memberikan petunjuk belajar, baik petunjuk untuk guru maupun petunjuk untuk siswa. Padahal, petunjuk belajar dapat membantu guru dan siswa dalam mencapai materi yang diajarkan. Kedua, di dalam buku tidak mencantumkan indicator yang hendak dicapai.

Ketiga, dalam buku teks tidak memuat materi yang lengkap. Hal ini dapat dilihat dari isi materi yang hanya menyajikan citraan dalam puisi, dan buku teks tersebut juga tidak memberikan contoh puisi. Keempat, bahasa yang digunakan dalam buku teks sulit untuk dipahami. Selain itu, di dalam buku teks tidak dilengkapi sama sekali dengan ilustrasi gambar.

Kelima, dalam buku teks memuat latihan yang tidak sesuai dengan hal yang hendak dicapai. Hal ini dapat dilihat dari soal yang seharusnya latihan berupa unjuk kerja menulis puisi. Akan tetapi, dalam buku tersebut latihannya berupa soal pilihan ganda.

Keenam, dalam buku teks, khususnya pembelajaran menulis puisi tidak memuat rubrik penilaian. Ketujuh, dalam buku teks tidak dilengkapi dengan evaluasi yang dapat mendukung setiap penilaian. Baik itu untuk menulis kreatif puisi berkenaan dengan keindahan alam maupun menulis kreatif puisi berkenaan dengan peristiwa yang dialami. 
Untuk mengatasi masalah tersebut, perlu bahan ajar seperti berikut. (1) Bahan ajar yang lengkap, jelas, dan contoh-contoh puisi yang bervariasi. (2) Bahan ajar yang dekat dengan lingkungan tempat siswa sekolah. (3) Bahan ajar yang memberikan materi puisi yang lengkap.

Bahan ajar sebagai media pembelajaran dipandang sebagai alat untuk meningkatkan efektivitas siswa dalam belajar. Tersedianya bahan ajar yang efektif, efisien dan sesuai dengan kebutuhan siswa dapat membantu kegiatan belajar siswa menjadi lebih baik. Bahan ajar yang digunakan dalam proses pembelajaran, bila disusun dan dipilih dengan baik dan sesuai dengan kebutuhan guru dan siswa dapat meningkatkan mutu pembelajaran. Selain itu, siswa dapat mempelajari dan memahami materi pelajaran tanpa bergantung kepada guru sehingga siswa tidak menjadi siswa yang monoton. Akan tetapi, menjadi siswa yang aktif dalam belajar. Sehubungan dengan bahan ajar tersebut, peneliti mengembangkan bahan ajar berbentuk buku teks.

(Setiawan, 2007) bahan ajar seperti buku teks dianggap sebagai bahan yang dapat dimanfaatkan, baik oleh guru maupun siswa dalam proses pembelajaran dan bertujuan untuk memperbaiki dan meningkatkan efektivitas pembelajaran siswa.

Mengingat pentingnya menulis puisi bagi siswa, perlu dikembangkan bahan ajar yang efektif, efesien, dan inovatif dalam rangka meningkatkan proses belajar dan meningkatkan kemampuan menulis siswa. Dalam penelitian pengembangan ini, peneliti mengembangkan bahan ajar menulis puisi yang diberi judul Asyik Menulis Puisi.

Penelitian mengenai menulis pernah dilakukan oleh Faulina Handayani dengan judul "Pengembangan Bahan Ajar Menulis Surat Untuk Siswa Kelas Xll" (2012). Hasil penelitian memperlihatkan peningkatan dari 58,77 menjadi 77,76 (persenstase peningkatan 32,65\%). Hasil tes tertulis menunjukkan peningkatan dari 50,49 menjadi 66,67 (persentase peningkatan $32,13 \%$ ).

Selanjutnya penelitian pengembangan menulis juga pernah dilakukan Aryanti Agustina dengan judul "Pengembangan Modul Keterampilan Menulis $l$ Program Studi Pendidikan Bahasa Sastra Indonesia dan Daerah Fakultas Keguruan dan Ilmu Pendidikan Universitas Baturaja” (2013). Hasil penelitian menunjukkan kemampuan menulis meningkat dan sudah mencapai nilai yaitu 70,74 .

Penelitian ini mempunyai persamaan dan perbedaan dengan kedua penelitian di atas. Persamaannya terletak pada jenis penelitian yaitu penelitian pengembangan menulis. Perbedaanya dengan penelitian sebelumnya yaitu terletak pada objek penelitian. Penelitian Faulina Handayani yaitu pengembangan bahan ajar menulis surat dengan pendekatan kontekstual dan berbentuk modul. Selanjutnya, penelitian Aryanti Agustina yaitu pengembangan modul keterampilan menulis 1 pada mahasiswa, se-dangkan penelitian ini adalah pengembangan bahan ajar menulis puisi untuk SMP kelas Vll.

Permasalahan dalam penelitian ini adalah. (1) Bagaimanakah kebutuhan guru dan siswa terhadap bahan ajar menulis puisi? (2)Bagaimanakah hasil validasi ahli terhadap pengembangan bahan ajar menulis puisi? (3) Bagaimanakah bahan ajar menulis puisi hasil pengembangan? (4) Bagaimanakah efek potensial buku teks hasil pengembangan terhadap pembelajaran menulis puisi siswa kelas VII SMP Negeri 1 Pagaralam?

Penelitian ini bertujuan untuk (1) Mendeskripsikan hasil kebutuhan guru dan siswa terhadap menulis puisi. (2) Mendeskripsikan hasil evaluasi dari validasi ahli terhadap bahan ajar menulis puisi berupa buku teks pada siswa SMP Negeri 1 Pagaralam. (3) Mendeskripsikan bahan ajar menulis puisi hasil pengembangan peneliti. 
Mendeskripsikan hasil pengembangan atau efek potensial bahan ajar menulis puisi siswa kelas Vll SMP Negeri 1 Pagaralam.

\section{LANDASAN TEORI}

1. Bahan Ajar

Menarut Pannen (Setiawan, 2007) menyatakan bahan ajar adalah bahan atau materi pelajaran yang disusun secara sistematis, yang digunakan guru dan siswa dalam proses pembelajaran.

Menurut (Nunan, 1992)agar bahan ajar dapat bermanfaat dalam membantu siswa mencapai tujuan belajar sesuai dengan kebutuhannya.

Menurut Richterich (Nunan, 1992) membagi kebutuhan-kebutuhan bahan ajar tersebut menjadi dua jenis yaitu: (1) kebutuhan objektif dan (2) kebutuhan subjektif. Kebutuhan objektif diperoleh dari analisis situasi komunikasi atau situasi berbahasa yang ditemukan oleh siswa sendiri. Kebutuhan objektif merupakan kebutuhan yang ditetapkan oleh guru mengenai cara terbaik suatu materi dipelajari. Sebaliknya, kebutuhan subjektif merupakan kebutuhan yang ditentukan sendiri oleh siswa tentang apa yang sebaiknya mereka pelajari.

Richard (Nurhayati, 2012) menyatakan bahwa analisis kebutuhan tersebut mempunyai tiga tujuan utama, yaitu sebagai berikut. (1) Analisis kebutuhan dapat menjadi sarana untuk memperoleh masukan terhadap isi, desain, dan implementasi program bahasa. (2) Analisis kebutuhan dapat digunakan untuk mengembangkan tujuan isi yang sedang berjalan. (3) Analisis kebutuhan dapat menyediakan data bagi penelaah dan penilaian program yang sedang berjalan. Sehubungan dengan pengembangan bahan ajar, analisis kebutuhan tersebut setidaknya memiliki fungsi untuk memperoleh masukan baik dari siswa maupun guru terhadap desain, isi, tujuan, dan bentuk serta teknik evaluasi bahan ajar yang dikembangkan.
Hasil analisis terhadap kebutuhan awal yang diperoleh dari guru dan siswa tersebut sangat menentukan suatu produk buku teks perlu dikembangkan atau tidak. Analisis kebutuhan yang dilakukan dalam penelitian pengembangan bahan ajar ini adalah analisis terhadap kebutuhan bahan ajar berdasarkan kebutuhan guru dan siswa.

\section{Buku Teks dan Komponen Buku Teks}

Menurut(Muslich, 2010) buku teks adalah buku yang disusun untuk menunjang suatu program pengajaran. Selanjutnya (Prastowo, 2011)menyatakan buku teks atau buku pelajaran merupakan bahan ajar hasil seorang pengarang atau tim pengarang yang disusun berdasarkan kurikulum atau tafsiran kurikulum yang berlaku.

Prastowo (2011:172) menyatakan bahan ajar berbentuk buku teks terdiri dari lima komponen yaitu (1) judul, (2) kompetensi dasar atau materi pokok, (3) informasi pendukung, (4) latihan, dan (5) penilaian.

bahan ajar yang dapat memudahkan belajar adalah bahan ajar yang memiliki komponen-komponen yang jelas. Komponen-komponen tersebut, yaitu sebagai berikut: (1) tujuan umum pembelajaran, (2) tujuan khusus pembelajaran, (3) petunjuk khusus penggunaan bahan ajar hasil pengembangan, (4) uraian isi pelajaran yang disusun secara sistematis, (5) gambar atau illustrasi untuk memperjelas isi pelajaran, (6) rangkuman, (7) evaluasi formatif, dan tindak lanjut untuk kegiatan belajar berikutnya, (8) daftar bacaan, dan (9) kunci jawaban.(Harijanto, 2007)

Jadi, dalam penelitian pengembangan buku teks, komponen-komponen adalah sebagai berikut, (1) petunjuk belajar, (2) judul, (3) kompetensi dasar atau materi pokok, (4) informasi pendukung, (5) latihan, (6) evaluasi, (7) rangkuman, (8) penilaian, (9) latihan akhir, (10) daftar pustaka. 


\section{Menulis Puisi}

Tim Penerbit buku Kumpulan Puisi Aroma Mewangi karya (Subadiyo, 2012) menyatakan "Menulis puisi dirasakan sangat penting dalam mengungkapkan pikiran dan perasaan ditengah kehidupan manusia dan kemanusian." Selanjutnya, (Syaddad, 2012)) menyatakan menulis puisi merupakan kegiatan menuangkan gagasan dan perasaan mengenai apa yang terjadi pada penulis maupun yang terjadi disekelilingnya.

(Sofyan et al., 2011)menyatakan bahwa menulis puisi bertujuan untuk meningkatkan kemampuan siswa dalam mengapresiasi karya sastra. Kegiatan mengapresiasi karya sastra berkaitan erat dengan latihan mempertajam perasaan, penalaran, dan daya khayal, serta kepekaan terhadap masyarakat, budaya serta lingkungan hidup. Secara lebih luas, menulis puisi adalah salah satu program untuk mengembangkan pemahaman, penghayatan, dan sikap positif terhadap karya sastra Indonesia.

Menurut (Wardisi, 2011) langkahlangkah menulis puisi, adalah sebagai berikut: (1) menentukan tema, tema merupakan gagasan pokok yang digunakan penyair dalam menulis puisi, yang mempunyai fungsi sebagai landasan utama penyair dalam puisinya. (2) Menentukan bentuk dan struktur puisi. Struktur puisi tersebut meliputi: pilihan kata, pengimajinasian, kata konkret, bahasa figuratif, versifikasi rima dan ritma.

\section{METODE PENELITIAN}

Penelitian ini adalah penelitian development (penelitian pengembangan). Pengembangan bahan ajar dalam penelitian ini mengadaptasi model pengembangan Jolly dan Bolitho (Tomlison, 1998).

Langkah-langkah pengembangan bahan ajar menurut Jolly dan Bolitho (Tomlison, 1998) adalah sebagai berikut: (1) Identifikasi kebutuhan bahan ajar. Pada tahap ini peneliti menganalisis kebutuhan bahan ajar oleh guru dan siswa berkaitan dengan kesulitan-kesulitan, dan kendala- kendala dalam menulis puisi dalam menggunakan bahan ajar yang sudah ada serta harapan-harapan guru dan sis-wa terhadap bahan ajar yang dikembangkan. (2) Eksplorasi kebutuhan. (3) Realisasi kontekstual bahan ajar. Penelitian pada tahap ini yaitu mengembangkan bahan ajar menulis puisi dengan melakukan analisis tujuan dan karakteristik materi, analisis sumber belajar, analisis karakteristik pembelajaran. (4) Realisasi pedagogik bahan ajar. Pada tahap ini pengembangan bahan ajar menulis dengan menetapkan strategi pengorganisasian isi pembelajaran, pengelolahan pembelajaran, dan dilengkapi dengan latihan-latihan serta tugas baik terstruktur ataupun tugas mandiri. (5) Produksi bahan ajar. Bahan ajar pengembangan disusun dalam bentuk buku yang dirancang sedemikian rupa terdiri dari komponen-komponen suatu buku agar dapat digunakan oleh siswa dan guru dalam pembelajaran menulis.(6) Validasi ahli. Tahap validasi dilakukan sebelum bahan ajar pengembangan digunakan siswa. Tujuannya untuk mendapatkan masukan tentang kualitas bahan ajar tersebut. Validasi ahli meliputi validasi oleh ahli. (a) kelayakan isi (b) keba-hasaan, (c) penyajian, dan (d) kegrafikaan. (7) Revisi bahan ajar. Pada tahap ini, peneliti merevisi bahan ajar pengembangan berdasarkan saran, informasi, dan masukan dari tim ahli. (8) Penggunaan bahan ajar oleh siswa. Tahap ini merupakan tahap ujicoba lapangan secara terbatas pada sekelompok siswa (1 kelas sebanyak 22 orang). (9) Evaluasi bahan ajar. Evaluasi ini merupakan evaluasi terhadap hasil belajar siswa sebelum dan sesudah menggunakan bahan ajar hasil pengembangan.

Subjek penelitian diambil dengan provosive sampling yaitu pengambilan sampel bertujuan(Sugiyono, 2012). Oleh karena itu, untuk identifikasi kebutuhan diambil sebanyak 66 orang siswa (3 kelas), sedangkan siswa yang menjadi subjek penelitian saat uji coba produk hasil pengembangan yaitu 22 orang siswa. 
Sementara itu, guru yang menjadi subjek penelitian adalah guru yang mengajar bahasa Indonesia di kelas Vll SMP Negeri 1 Pagaralam sebanyak 3 orang. Selanjutnya, ahli yang memvalidasi bahan ajar hasil pengembangan adalah 4 orang yang memiliki keahlian yang berbeda, yaitu ahli materi atau isi bahan ajar, ahli kebahasaan, ahli penyajian, dan ahli kegrafikaan.

Teknik pengumpulan data dalam penelitian ini adalah angket (kuesioner). Untuk memperoleh informasi tentang kebutuhan bahan ajar menulis puisi digunakan angket terbuka yang diberikan kepada siswa dan guru. Angket yang diberikan kepada siswa dan guru ini dimaksudkan untuk memperoleh informasi terkait dengan harapan-harapan dan kesulitan-kesulitan yang dihadapi siswa dalam pembelajaran menulis puisi. Angket juga digunakan peneliti untuk menjaring data tentang materi pembelajaran, strategi, metode pembelajaran, evaluasi (penilaian), tugas-tugas/latihan yang diinginkan oleh siswa dan guru.

Teknik angket digunakan juga pada saat validasi oleh tim ahli. Hal ini bertujuan untuk mendapatkan informasi kualitas produk bahan ajar yang dikembangkan berupa bahan ajar menulis puisi. Angket yang diberikan kepada pakar/ahli digunakan untuk memperoleh informasi tentang kualitas bahan ajar.

Selanjutnya, pengumpulan data juga menggunakan teknik wawancara. Wawancara ditujukan kepada siswa dan guru untuk mendapatkan informasi yang berkenaan dengan hasil bahan ajar hasil pengembangan.

Untuk memperoleh informasi tentang efek potensial penggunaan bahan ajar yang dikembangkan, peneliti melakukan tes kepada siswa yaitu berupa tes unjuk kerja menulis puisi (bersifat praktik).

Data penelitian ini berupa data kualitatif dan data kuantitatif. Adapun langkah-langkah penganalisisan data adalah sebagai berikut. langkah-langkah peng-analisan angket dari guru dan siswa adalah sebagai berikut: (1) data angket diperiksa dan diklasifikasikan secara objektif, (2) data angket dianalisis dan dideskripsikan, (3) data angket evaluasi tim ahli dianalisis secara deskriptif dengan menggunakan skor, dideskripsikan serta ditarik kesimpulan.

Selanjutnya, langkah-langkah analisis data tes dalam penelitian ini yaitu sebagai berikut. (1) Data skor hasil tes dianalisis dengan melihat perbedaan antara skor hasil tes siswa sebelum dan sesudah menggunakan bahan ajar hasil pengembangan peneliti. (2) Data tes diidentifikasi dan diklasifikasikan berdasarkan komponen dan jenis bahan ajar yang dikembangkan. (3) Data tes disajikan dalam bentuk tabel, grafik, kurva. (4) Data tes dianalisis dengan menggunakan uji-t melalui SPSS 16. Jika hasil uji t lebih besar dari pada $t$ tabel dengan signifikan 0,05, pengembangan bahan ajar dapat dikatakan lebih baik. Sebaliknya jika hasil uji t hitung lebih kecil dari pada $t$ tabel, pengembangan bahan ajar dapat dikatakan tidak berhasil dan perlu direvisi. (5) Memberikan simpulan terhadap hasil analisis data.

Sementara, data hasil wawancara yang dilakukan pada guru dan siswa diolah secara objektif, dideskripsikan, dan kemudian ditarik simpulan. Hasilnya digunakan untuk melengkapi data tes dan merevisi bahan ajar Menulis Puisi yang diberi judul Asyik Menulis Puisi berbentuk buku teks hasil pengembangan peneliti. 


\section{PEMBAHASAN}

\section{A. HASIL PENELITIAN}

\section{Identifikasi Kebutuhan Siswa}

Berdasarkan jawaban angket ditunjukkan bahwa bahwa $68 \%$ persen siswa tidak senang menulis puisi, $10 \%$ terkadang senang, dan $22 \%$ senang menulis puisi.

Sehubungan dengan bahan ajar yang digunakan dalam pembelajaran di kelas. Jawaban angket menunjukkan, subjek penelitian mengaku mengalami beberapa kesulitan, antara lain sebagai berikut. (1) Kesulitan memahami materi, (2) kesulitan mencari diksi, (3) kesulitan mencari ide dan menuliskanya ke dalam bait-bait puisi, (4) siswa mengalami kesulitan menggunakan bahasa secara konotatif, (5) terkait dengan contoh-contoh puisi. Bahan ajar yang digunakan hanya ada satu contoh puisi.

Ketika ditanya tentang bahan ajar buku teks khusus menulis puisi, 99\% subjek penelitian mengaku belum pernah membaca buku khusus menulis puisi. Oleh karena itu, dari hasil jawaban angket diperoleh informasi, bahwa mereka mengharapkan buku teks khusus menulis puisi. Harapan mereka diantaranya, adalah sebagai berikut.

Pertama, sebanyak 64 (97\%) subjek mengharapkan di dalam buku teks yang dikembangkan materinya harus lebih jelas. Dilengkapi dengan penjelasan diksi, rima, majas, denotasi, konotasi, contoh-contoh puisi yang bervariasi, langkah-langkah menulis puisi, dan rubrik penilaian. Selain itu, subjek penelitian mengharapkan di dalam buku teks yang dikembangkan memberikan contoh-contoh diksi, majas yang biasa terdapat dalam puisi-puisi.

Kedua, berkenaan dengan topiktopik yang diinginkan dalam bahan ajar menulis puisi. 43 orang siswa (66\%) memerlukan topik keindahan alam yang berkaitan dengan kota Pagaralam untuk dijadikan tema dalam menulis puisi. Sebanyak 23 orang siswa atau (35\%) memerlukan topik sahabat yang akan dijadikan puisi. Selanjutnya, 30 orang siswa (45\%) memerlukan topik ayah, ibu, dan guru (kepahlawanan) untuk dituliskan menjadi puisi.

Ketiga, berkaitan dengan kegiatan belajar. Subjek penelitian menginginkan ke-giatan, antara lain yaitu kegiatan berdasarkan sifatnya dan kegiatan berdasarkan bentuknya.

Keempat, harapan siswa yaitu berkenaan dengan tugas atau latihanlatihan. Sebanyak 20 orang siswa $(30 \%)$ meng-inginkan latihan menunjukkan diksi, dan majas terlebih. Selanjutnya baru menulis puisi yang lengkap. Sementara itu, 46 orang siswa $(70 \%)$ menginginkan latihan untuk melanjutkan bagian-bagian kalimat rumpang dalam puisi.

Kelima, berkenaan dengan media dalam buku teks yang diinginkan siswa dalam bahan ajar menulis puisi yaitu 63 orang siswa (96\%) menginginkan dalam bahan ajar yang dikembangkan dilengkapi dengan gambar yang berkaitan dengan tema yang akan ditulis menjadi puisi.

Keenam, terkait dengan evaluasi dalam bahan ajar menulis puisi. Siswa mengharapkan evaluasinya yaitu unjuk kerja menulis puisi sesuai dengan tema yang telah ditentukan.

\section{Identifikasi Kebutuhan Guru}

Identifikasi kebutuhan kepada tiga guru. Informasi kebutuhan guru tersebut diperoleh melalui kuesioner yang diberikan kepada guru yang bertugas di SMP Negeri 1 Pagaralam.. 
Berdasarkan analisis kebutuhan guru ter-hadap bahan ajar menulis puisi. Hasilnya menunjukkan adanya kebutuhan yang relatif sama. Jawaban angket menunjukan ketiga guru bahasa Indonesia di SMP Negeri 1 Pagaralam, senang memberikan materi menulis puisi.

Selanjutnya, berdasarkan jawaban angket diperoleh bahwa ketiga guru memerlukan buku teks khusus menulis puisi lengkap. Harapan-harapan yang diinginkan guru, antara lain yaitu ketiga guru memer-lukan buku teks yang menyertakan materi.

Bentuk penyajian materi, yang diinginkan ketiga guru tersebut yaitu bahan ajar tersebut sedikit menjelaskan diksi dan majas.

Selanjutnya, ketiga guru juga menginginkan perlu adanya contoh-contoh puisi yang menarik dan bervariasi, dan guru juga menginginkan perbanyak latihan menulis puisi sesuai dengan tema yang dipilih siswa.

Berkenaan dengan tugas-tugas yang diberikan, jawaban angket menunjukkan guru menginginkan adanya ilustrasiilustrasi. gambar dalam latihan. Ketiga guru meng-inginkan adannya tugas atau latihan mele-ngkapi bagian puisi yang rumpang.

Selanjutnya berkaitan dengan evaluasi yang diinginkan dalam bahan ajar menulis puisi. Sebanyak tiga guru mengharapkan evaluasi berupa tes. Tes tersebut berupa tes unjuk kerja.

Berkaitan dengan media dan bentuk perwajahan, sebanyak 3 orang guru menginginkan dalam bahan ajar menulis puisi yang dikembangkan oleh peneliti dilengkapi dengan gambar-gambar yang menarik.

Berkenaan dengan pemahaman siswa dalam menulis puisi. Jawaban angket menunjukkan bahwa kemampuan siswa dalam menulis puisi bervariasi.

Selanjutnya, berkenaan dengan kendala-kendala yang dialami siswa. Jawaban angket menunjukkan bahwa kendala atau kesulitan siswa dalam menulis puisi yaitu sebagai berikut. (1) Siswa sulit memilih diksi yang tepat untuk menulis puisi. Faktor yang menjadi penyebab kendala atau kesulitan tersebut yaitu tidak lengkapnya materi yang membahas tentang diksi. (2) Siswa kesulitan menuangkan kata-kata ke dalam bait-bait puisi. Hal ini disebabkan, di dalam buku teks tersebut tidak menyajikan langkah-langkan menulis puisi. (3) Siswa kesulitan mem-berikan bahasa yang bersifat konotatif dalam menulis puisi. Hal ini disebabkan dalam buku teks tidak memberikan contoh majas yang apa saja yang digunakan dalam menulis puisi.

\section{Hasil Validasi dan Pengembangan \\ 1) Hasil Validasi}

Validasi terhadap buku tersebut meliputi. (1) kelayakan isi (materi), (2) keba-hasaan, (3) penyajian, dan (4) kegrafikaan.

Berdasarkan hasil penilaian, komponen kelayakan isi dapat dikatagorikan baik. Dari lima aspek penilaian dengan skala 5. Aspek kesesuai dengan standar kompetensi dan kompetensi dasar memperoleh skor 4 (baik), aspek kesesuai dengan kebutuhan siswa memperoleh skor 4 (baik), aspek kesesuaian dengan kebutuhan bahan ajar memperoleh skor 4 (baik), aspek kebenaran subtansi materi memperoleh skor 4 (baik), dan aspek manfaat untuk penambahan wawasan pengetahuan dengan skor 4 (baik) secara keseluruhan dari skor maksimal 25, komponen kelayakan isi memperoleh skor 
20 artinya kelayakan isi/materi bahan ajar yang dikembangkan termasuk kategori baik.

Selanjutnya, penilaian prototipe bahan ajar yang telah dikembangkan pada aspek kebahasaan dapat dikatagorikan baik. Dari 4 aspek yang dinilai dengan penilaian skala 5. Aspek keterbacaan memperoleh skor 4 (baik). Aspek kejelasan informasi mem-peroleh skor 4 (baik). Kesesuai dengan bahasa Indonesia memperoleh skor 4 (baik). Penggunaan bahasa secara umum cukup efektif dan efesien memperoleh skor 4 Secara keseluruhan, skor yang diperoleh untuk komponen kebahasaan adalah 16 dari skor maksimal 20.

Dilihat dari aspek penyajian/sajian, bahan ajar yang dikembangkan dapat dikatagorikan baik. Dari lima aspek yang dinilai dengan menggunakan skala 5. Tiga aspek mendapatkan skor 3, dan 2 aspek skor4. Aspek kejelasan tujuan mendapatkan skor 3. Urutan penyajian mendapatkan skor 3. Aspek pemberian motivasi memperoleh skor 4. Aspek interaktivitas (stimulus dan respon) memperoleh skor 4. Aspek kelengkapan informasi memperoleh skor 3. Dengan demikian, skor yang diperoleh aspek penyajian berjumlah 17 dan dapat dikatagorikan baik.

Hasil penilaian terhadap empat aspek komponen kegrafikaan dengan menggunakan skala 5 dapat dikatagorikan dengan baik. As-pek ukuran dan jenis huruf mendapatkan skor 4 (baik). Aspek ketepatan ilustrasi gambar, grafik, dan tabel memperoleh skor 5 (sangat baik). Aspek cover memperoleh skor 4 (baik). Aspek tampilan fisik memperoleh skor 4 (baik). Secara keseluruhan aspek ke-grafikaan dari skor maksimal 25, aspek kegrafikaan memperoleh skor 21. Artinya, aspek kegrafikaan bahan ajar yang dikembangkan termasuk kategori baik.

Berdasarkan saran dari pakar ahli tersebut, hasil pengembangan prototipe dalam penelitian ini yaitu buku siswa. Buku siswa adalah buku teks atau buku pelajaran yang dapat digunakan baik dengan guru, atau tanpa guru. Buku teks ini terdiri dari 3 bab dan 62 halaman.

Buku teks yang dikembangkan dalam penelitian ini terdiri dari 3 bagian dan bersifat subtantif. Artinya buku ini terdiri dari pendahuluan, isi, dan penutup.

Komponen pendahuluan terdiri atas sampul atau cover depan, kata pengantar, petunjuk guru, dan daftar isi.

Sementara itu, bagian isi terdiri dari beberapa kegiatan pembelajaran dengan masing-masing kegiatan meliputi: judul kegiatan, kompetensi dasar (KD), indikator, uraian pengantar berisi tujuan pembelajaran, uraian materi dan informasi, latihan, evaluasi, penilaian, dan rangkuman.

Bagian penutup terdiri dari: latihan akhir, daftar pustaka, dan biodata singkat.

\section{Hasil Uji Lapangan}

Uji lapangan ini merupakan uji lapangan terbatas dilaksanakan di Sekolah Menengah Pertama Negeri 1 Pagaralam. Uji lapangan telah menggunakan bahan ajar hasil pengembangan peneliti yang diberi judul Asyik Menulis Puisi.

menulis puisi yang terdapat dalam bahan ajar hasil pengembangan peneliti.

Tes unjuk kerja menulis puisi diukur dengan tema yang berbeda-beda, diantaranya adalah menulis puisi keindahan alam, kepahlawanan (ibu, ayah, guru), dan sahabat. Tes tersebut dilakukan sebelum dan sesudah menggunakan bahan ajar hasil penge-mbangan. 


\section{a. Nilai Tes Menulis Puisi Kepahlawanan}

Tes menulis puisi kepahlawanan ini disediakan tiga tema yaitu ibu, ayah, dan guru. Hasil pretes tes menulis puisi kepahlawanan tersebut memperlihatkan nilai yang bervariasi. Nilai tertinggi 70 diperoleh oleh satu orang. Sementara, nilai terendah 40 yang diperoleh satu orang. Nilai rata-rata siswa menulis puisi kepahlawanan sebelum menggunakan bahan ajar hasil pengembangan peneliti adalah 59,09 dengan standar deviasi 6, 502.

Sementara menulis puisi kepahlawanan setelah menggunakan bahan ajar hasil pengembangan. Berdasarkan hasil tes diperoleh nilai yang cukup bervariasi. Nilai tertinggi 90 yang diperoleh satu orang siswa dan nilai terendah 62 yang diperoleh satu orang. Nilai rata-rata menulis puisi kepah-lawanan setelah menggunakan bahan ajar hasil pengembangan 80,95 dengan standar deviasi 7,435 .

\section{Tabel 2 \\ Statistik Deskriptif}

Nilai Tes Menulis Puisi Kepahlawanan

\begin{tabular}{|l|l|l|l|l|l|}
\hline & $\mathrm{N}$ & $\begin{array}{l}\text { Minimu } \\
\mathrm{m}\end{array}$ & $\begin{array}{l}\text { Maximu } \\
\mathrm{m}\end{array}$ & Mean & $\begin{array}{l}\text { Std. } \\
\text { Deviation }\end{array}$ \\
\hline Pretest & 22 & 40 & 70 & 59.09 & 6.502 \\
Posttest & 22 & 62 & 90 & 80.95 & 7.435 \\
$\begin{array}{l}\text { Valid N } \\
\text { (listwise) }\end{array}$ & 22 & & & & \\
\hline
\end{tabular}

Selanjutnya hasil uji t paired simple test pada menulis puisi kepahlawanan menunjukkan nilai rata-rata pada pretes dan postes menulis puisi kepahlawanan adalah 21,864 dengan standar deviasi 7,337 dan sig (2-tailed) 0,00. Angka 0,00 lebih kecil dari alpha value yaitu 0,05. Dengan demikian, dapat disimpulkan bahwa adanya perbedaan nilai menulis puisi kepahlawanan yang signifikan antara nilai sebelum menggunakan bahan ajar dan setelah menggunakan bahan ajar Asyik Menulis Puisi hasil pengem-bangan.

\section{b. Nilai Tes Menulis Puisi Sahabat}

Hasil penilaian menulis puisi sahabat menunjukkan nilai-nilai yang bervariasi. Hal ini dapat dilihat dari nilai tertinggi adalah 68 yang diperoleh oleh 1 orang siswa, sedangkan nilai terendah adalah 50 yang diperoleh oleh 4 orang siswa. Jadi, nilai rata-rata siswa sebelum menggunakan bahan ajar adalah 56,68 dengan standar deviasi 5,140.

Sementara, tes menulis puisi sahabat setelah mengunakan bahan ajar hasil pengembangan. Berdasarkan hasil tes diperoleh nilai yang cukup bagus. Hal ini dibuktikan nilai tertinggi yang diperoleh siswa 88 dan nilai terendah 65. Sementra nilai rata-rata yang diperoleh siswa setelah menggunakan bahan ajar hasil pengembangan mengalami peningkatan yaitu 76,55 dengan standar deviasi 5,755.

Tabel 3

\section{Statistik Deskriptif Nilai Tes Menulis Puisi Sahabat}

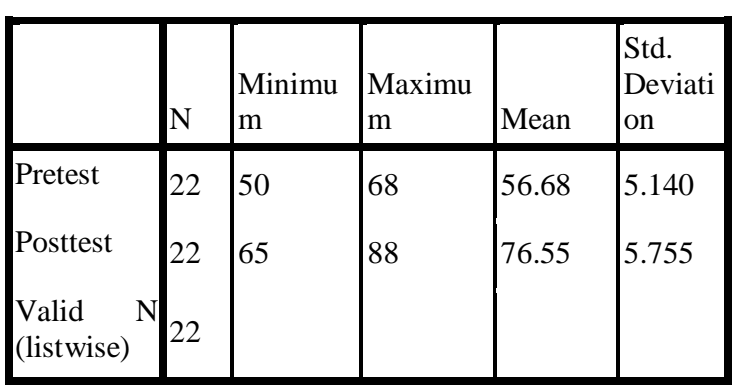

Selanjutnya, pada tes menulis puisi sahabat juga dilakukan uji-t. Peneliti menggunakan uji-t yaitu paired simple uji$t$ melalui program SPSS 16. Berdasarkan hasil uji t dengan paired simple test pada menulis puisi sahabat menunjukkan nilai rata-rata pada pretes dan postes menulis puisi sahabat adalah 19,864 dengan standar deviasi 6,840 dan sig (2-tailed) 0,00. Angka 0,00 lebih kecil dari alpha value yaitu 0,05. Dengan demikian, dapat disimpulkan bahwa adanya perbedaan nilai menulis puisi sahabat yang signifikan antara nilai sebelum menggunakan bahan ajar dan setelah menggunakan bahan ajar Asyik Menulis Puisi hasil pengembangan. 


\section{Hasil Wawancara}

Wawancara kepada siswa dilakukan sebanyak dua orang siswa yang telah mengikuti pembelajaran menulis puisi dengan buku Asyik Menulis Puisi. Kedua orang siswa tersebut dipilih untuk mewakili seluruh siswa yang dijadikan subjek penelitian. Berdasarkan hasil wawancara terhadap buku teks hasil pengembangan peneliti sudah baik.

Berkaitan dengan materi, hasil wawancara diperoleh bahwa bahan ajar Asyik Menulis Puisi hasil pengembangan peneliti, mudah dipahami. Hal ini disebabkan dalam buku teks tersebut dilengkapi dengan langkah-langkah menulis puisi dan dilengkapi dengan contoh puisi yang bervariasi.

Selanjutnya hasil wawancara kepada guru. Wawancara kepada guru dilakukan oleh peneliti sebanyak dua orang. Hasil wawancara menunjukkan jika materi yang terdapat dalam buku teks Asyik Menulis Puisi sudah baik. Hal ini berkaitan dengan diksi, majas, dan langkah-langkah menulis puisi sudah ada dalam buku teks khusus tersebut. Selain itu, sebelum diadakan evaluasi siswa diberi latihan yaitu melengkapi puisi yang rumpang dengan bahasa mereka sendiri.

\section{PEMBAHASAN}

Berdasarkan hasil identifikasi kebutuhan yang dilakukan peneliti terhadap siswa SMP Negeri 1 Pagaralam. Diperoleh data bahwa siswa SMP Negeri 1 Pagaralam mengalami beberapa kesulitan dalam menulis puisi.

Untuk memenuhi kebutuhan bahan ajar yang mudah dipahami. Di dalam bahan ajar tersebut dilengkapi dengan materi yang lengkap. Materi tersebut dilengkapi dengan langkah-langkah menulis puisi, contoh unsur-unsur puisi (diksi, rima, dan majas), rubrik penilaian, dan dilengkapi dengan contoh puisi yang bervariasi yang didapat dari surat kabar Pagaralam Post, Majalah Horison, dan puisi karya siswa SMP Negeri 1 Pagaralam.
Selanjutnya untuk memenuhi kebutuhan siswa terhadap bahan ajar yang menyenangkan, bahan ajar diberi judul Asyik Menulis Puisi dan dilengkapi cover berwarna biru, dan di cover tersebut dilengkapi dengan gambar siswa SMP. Selain itu, hasil pengembangan peneliti memberikan motivasi dan menarik minat siswa untuk membaca dan mempelajari buku Asyik Menulis Puisi. Kebutuhan tersebut antara lain dapat dipenuhi melalui gambar, warna, dan ilustrasi yang menarik. Dengan adanya tampilan yang disertai dengan ilustrasi serta warna memotivasi siswa untuk mempelajari buku tersebut. Sementara itu, untuk latihan dan evaluasi. Subjek peneliti memerlukan latihan-latihan melengkapi bagian puisi rumpang, dan evaluasi secara individu dengan tema puisi yang telah ditentukan

Begitu juga dengan hasil kebutuhan guru. Hasil kebutuhan guru relatif sama yaitu membutuhkan bahan ajar yang mudah dipahami. Untuk memenuhi kebutuhan guru dan siswa mengenai materi-materi menulis puisi agar mudah dipahami peneliti mengadopsi puisi dari koran Pagaralam Pos, Majalah Horison, dan Puisi hasil siswa SMP Negeri 1 Pagaralam.

Selanjutnya, di dalam buku teks tersebut agar siswa mudah memahami materi menulis puisi dilengkapi dengan langkah-langkah menulis puisi, unsurunsur puisi serta contoh yang terdapat dalam puisi yang meliputi diksi, rima, dan majas. Selanjutnya, setelah siswa memahami unsur-unsur dalam puisi dan memahami langkah-langkah menulis siswa diberi tugas latihan dan evaluasi menulis puisi sesuai dengan tema yang telah ditentukan.

Selanjutnya untuk memotivasi siswa dalam menulis puisi guru mengharapkan di dalam bahan ajar harus memperhatikan peng-gunaan bahasa, pemilihan kata, penggunaan kalimat yang efektif. Selain penggunaan bahasa untuk memotivasi siswa guru mengharapkan bentuk perwajahan berupa gambar dan ilustrasi yang menarik dan bervariasi, 
sehingga dapat menimbulkan ketertarikan siswa untuk menulis puisi.

Dari hasil identifikasi kebutuhan guru dan siswa. Di peroleh prototipe bahan ajar dengan judul buku Asyik Menulis Puisi. Prototipe bahan ajar tersebut dilengkapi dengan komponen-komponen buku teks sebagai berikut. (1) petunjuk belajar, (2) judul, (3) kompetensi dasar atau materi pokok, (4) informasi pendukung, (5) latihan, (6) evaluasi, (7) rangkuman, (8) penilaian, (9) latihan akhir, (10) daftar pustaka.

Selanjutnya sebelum bahan ajar hasil pengembangan peneliti diberikan kepada siswa SMP Negeri 1 Pagaralam. Bahan ajar berupa teks ini dilakukan validasi ahli. Validasi ahli tersebut meliputi (1) kelayakan isi (materi), (2) kebahasaan, (3) penyajian, dan (4) kegrafikaan. Hasil validasi terhadap bahan ajar Menulis Puisi yang diberi judul Asyik Menulis Puisi menyatakan bahan ajar tersebut sudah baik. Hasil pengembangan peneliti dapat dinyatakan layak digunakan oleh siswa siswa SMP Negeri 1 Pagaralam.

Setelah diperoleh hasil prototipe dan hasil validasi ahli diperoleh hasil penge-mbangan yang terdiri dari tiga bagian yakni bagian pendahuluan yang terdiri dari (1) sampul atau cover, (2) kata pengantar, (3) petunjuk guru, (4) daftar isi. Selanjutnya ba-gia isi terdiri dari (1) judul kegiatan, (2) standar kompetensi, kompetensi dasar, in-dikator, (3) tujuan pembelajaran, (4) uraian materi, (5) latihan, (6) evaluai, (7) rang-kuman. Sementara itu bagian penutup terdiri dari (1) latihan akhir, (2) daftar pustakan, dan (3) biodata singkat penulis.

Berdasarkan hasil uji lapangan yang diberikan pada 22 orang siswa SMP Negeri 1 Pagaralam kelas VII dalam menulis puisi (kepahlawanan, sahabat) menunjukkan peningkatan dalam menulis puisi. Hal ini dibuktikan dengan hasil tes menulis puisi setelah siswa menggunakan bahan ajar hasil pengembangan peneliti nilai rata-rata siswa menulis puisi keindahan alam, kepahlawanan, dan sahabat meningkat.
Peningkatan tersebut dipengaruhi oleh beberapa faktor, yaitu sebagai berikut: (1) kecermatan isi. Kecermatan isi dalam bahan ajar ini meliputi (a) bahan yang dibuat sesuai dengan tema yang diinginkan siswa, (b) bahan ajar dilengkapi dengan materi yang mudah dipahami, seperti langkah-langkah menulis puisi, (c) bahan ajar yang dilengkapi dengan contoh yang bervariasi, (d) bahan ajar dilengkapi dengan rubrik penilaian, (2) ketepatan cakupan, melipti kesesuai standar kompetensi, dan kompetensi dasar, dengan kurikulum, (3) penyajian materi yang sistematis, (4) disajikan dengan tampilan/ gambar ilustrasi yang menarik, (5) penggunaan bahasa dan pilihan kata yang efektif. Dengan demikian, kegiatan pembelajaran menulis puisi dapat dilakakukan dengan siswa lebih baik dan efektif.

Menutur (Setiawan, 2007) bahan ajar yang baik adalah bahan ajar yang sesuai dengan karakteristik siswa dan tujuan pembelajaran yang dicapai. Bahan ajar juga harus disajikan secara sistematis, lengkap, memiliki daya tarik, menggunakan bahasa yang mudah dipahami. Demikian pula, menurut (Prastowo, 2011) bahan ajar yang baik adalah bahan ajar yang disusun harus sesuai dengan karakteristik siswa dan menampilkan sosok utuh dari kompetensi yang akan dikuasai oleh siswa dalam proses pembelajaran.

Dengan demikian dapat disimpulkan hasil identifikasi kebutuhan bahan ajar guru dan siswa relatif sama dengan tujuan untuk meningkatkan kemapuan siswa dalam menulis puisi di dalam kelas. Prototipe bahan ajar hasil pengembangan telah dikembangkan berdasarkan kebutuhan guru dan siswa SMP Negeri 1 Pagaralam. Selanjutnya, hasil perhitungan uji-t juga menunjukkan pengaruh yang positif terhadap hasil belajar siswa setelah menggunakan bahan ajar.

\section{PENUTUP}

Berdasarkan hasil penelitian dan pembahasan dapat ditarik beberapa 
simpulan. Pertama, siswa SMP Negeri 1 kelas VII memiliki kebutuhan yang beragam dalam menulis puisi.

Kedua, bahan ajar yang dihasilkan dalam penelitian ini memiliki spesifikasi (1) mencontohkan pembuatan puisi (2) menyajikan gambar yang diperlukan untuk memotivasi siswa dalam melaksanakan latihan dan evaluasi menulis puisi (3) menyajikan contoh puisi yang bervariasi (4) menyajikan beberapa warna.

Ketiga, bahan ajar menulis puisi yang diberi judul Asyik Menulis Puisi layak digunakan dalam pembelajaran di sekolahdi sekolah lain. Terutama pada sekolahsekolah yang memiliki karakteristik yang sama dengan sekolah tempat bahan ajar ini di ujicoba.

Keempat, bahan ajar menulis puisi hasil pengembangan yang berupa berupa buku teks dengan spesifikasi seperti dikemukakan di atas dapat meningkatkan kemampuan siswa dalam menulis puisi. Peningkatan tersebut dapat dilihat dari hasil nilai rata-rata sebelum dan sesudah siswa menggunakan bahan ajar hasil pengembangan peneliti yang mengalami peningkatan baik kepahlawanan, dan sahabat.

\section{DAFTAR ISI}

Harijanto, M. (2007). Pengembangan Bahan Ajar untuk Peningkatan Kualitas Pembelajaran Program Pendidikan Pembelajaran Sekolah Dasar. 2(1), 216-226.

Maulana, S. F. (2011). Apresiasi dan roses Kreatif Menulis Puis. Bandung:
Nuasa.

Muslich, M. (2010). No TitleText Book Writing. Yogyakarta: Er-Ruzz Media.

Nunan, D. (1992). The Learner-Centered Curriculum: A Study In Second. Amarica: Cambridge University Press.

Nurhayati. (2012). Silabus: Teori dan Aplikasi Pengembangannya. Yogyakarta: Leutika Prio.

Prastowo, A. (2011). Panduan Kreatif Membuat Bahan Ajar Inovatif: Menciptakan Metode Pembelajaran yang Menarik dan Menyenangkan. Yogyakarta: Diva Press.

Setiawan, D. (2007). Pengembangan Bahan Ajar. Jakarta: Universitas Terbuka.

Sofyan, Wiryotinoyo, M., \& Sudaryono. (2011). Pengembangan Media Audio Visual Dalam Pembelajaran Menulis Kreatif Puisi. Tekno-Pedagogi, 1(1), 25-32.

Sugiyono. (2012). Kualitatif dan $R \& D$; Metode Penelitian Kuantitatif. Bandung: Alfabeta.

Syaddad, A. (2012). Strategi Pembelajaran Menulis Kreatif Puisi. Depok: Indie Publishing.

Tomlison, B. (1998). Materials Development In Language Teaching. Cambridge: Cambridge University Press.

Wardisi, E. (2011). Pengetahuan Tentang Puisi. Bandung: PT. Sarana Ilmu Pustaka. 